\title{
The Effect of Dietary Inclusion of Jatropha curcas Kernel Meal on Growth Performance, Feed Utilization Efficiency and Survival Rate of Juvenile Nile tilapia
}

Kassaye Balkew Workagegn*, Elias Dadebo Ababbo and Bishaw Tadele Tossa

Department of Biology, College of Natural and Computational Sciences, Hawassa University, P.O. Box 5, Hawassa, Ethiopia

\begin{abstract}
The study investigated the effect of dietary inclusion of different proportion of heat treated and heat untreated Jatropha curcas kernel meal (JCKM) on growth performance, feed utilization efficiency and survival rate of juvenile Nile tilapia. Ten fish with an average body weight of $2.36 \mathrm{~g}$ fish-1 were randomly distributed in each experimental aquarium in triplicates, and fed with experimental diets for 65 days. The results revealed that the highest growth performance in terms of final body weight and specific growth rate was observed on the fish fed with heat treated control diet followed by heat untreated control diet and $10 \%$ heat treated JCKM with same survival rate. Similarly, the best feed utilization efficiency in terms of feed conversion ratio and feeding efficiency was observed on the fish fed with heat treated control diet followed by $10 \%$ heat treated JCKM and heat untreated control diet.

All fish fed the above three diets had higher growth performance, feed utilization efficiency and survival rate without significant $(P>0.05)$ variation to each other. However, fish fed with the rest of the experimental diets had significantly $(P<0.05)$ lower. Thus, the inclusion of excess dietary JCKM (above $10 \%$ heat treated dietary JCKM and at any level of heat untreated dietary JCKM) depressed growth performance, feed utilization efficiency and survival rate of the fish. This implies that heat treatment has an effect on reduction of some of anti-nutritional factors and toxicants in JCKM. In conclusion, dietary inclusion of heat treated JCKM in fish diet increases growth performance and feed utilization efficiency of the fish without increasing mortality rare, and thus, it is a future promising feed ingredient for fish feed production.
\end{abstract}

Keywords: Alternative feed source; Feed ingredient; Performance; Oreochromis niloticus

\section{Introduction}

The price of fish feed covers from 50 to $60 \%$ of the total operation cost of aquaculture production [1-3]. The responsible factor for the increment of fish feed production and its price is the rapid growth rate of aquaculture industry [4]. The limited source of feed ingredients such as fish meal, fish oil and soybean meal are also the main reason to increase the price of aqua-feed. Moreover, an increasing of human demand for nutrients derived from those ingredients could reduce the contribution of those feed ingredients towards satisfying the demand for sustainable aqua-feed production. Therefore, there is serious concern on the long-term availability of these feed ingredients for use in aqua-feed production [5-8]. The need to identify alternative source of protein to develop low-cost feed ingredients on the basis of sustainable and renewable feed resources for small and medium scale fish farmers are therefore, crucial $[3,9]$. It is also important to consider that the selected feed ingredients do not conflict with human food security interests $[9,10]$. For these reasons, Jatropha curcas is expected to be one of the potential plant species to be a cheap protein source for fish feed production in the future if anti-nutritional factors and toxicants are detoxified.

Jatropha curcas is a multipurpose plant species which is widely distributed in many tropical and subtropical countries [6,11]. Recently, this plant is highly cultivated for commercial production of bio-diesel $[6,12,13]$. The Jatropha curcas kernel meal obtained after oil extraction is also an excellent source of nutrients for animal feed if the anti-nutritional factors are reduced [7,8,11,14-16]. After oil extraction, about $50 \%$ of the weight of the seed remains as press cake, and contains $58-62 \%$ crude protein with an excellent amino acid profile and good proportion of carbohydrates [6]. Jatropha curcas can also a good source of both saturated and unsaturated fatty acids particularly, polyunsaturated fatty acids (PUFA) such as linoleic acid (18:2n-6) and alpha linoleic acid (18:3n-3) fatty acids [6]. Therefore, it is expected to be an excellent feed ingredient in the future to replace fish meal and soybean meal. Despite the fact that a high content of protein with an excellent amino acid profile and good proportion of carbohydrates, the levels of toxic substance (phorbol esters) and anti-nutritional substances (lectin, phytic acid, saponins and trypsin inhibitors) restricts its use in animal feed production [12]. The purpose of this research was therefore, to evaluate the effect of inclusion of different level of heat treated and heat untreated dietary JCKM within a major feed ingredients on growth performance, feed utilization efficiency and survival rate of juvenile Nile tilapia.

\section{Materials and Methods}

\section{Feed ingredients collection and diets formulation}

Jatropha curcas seed cack, a target feed ingredient, was collected

*Corresponding author: Kassaye Balkew Workagegn, Department of Biology, College of Natural and Computational Sciences, Hawassa University, P.O. Box 5, Hawassa, Ethiopia, Tel: +251921452893; Fax: +251462205421; E-mail: kassayebalkew@gmail.com

Received June 27, 2013; Accepted September 12, 2013; Published Septembe 21,2013

Citation: Workagegn KB, Ababbo ED, Tossa BT (2013) The Effect of Dietary Inclusion of Jatropha curcas Kernel Meal on Growth Performance, Feed Utilization Efficiency and Survival Rate of Juvenile Nile tilapia. J Aquac Res Development 4 193 doi:10.4172/2155-9546.1000193

Copyright: (C) 2013 Workagegn KB, et al. This is an open-access article distributed under the terms of the Creative Commons Attribution License, which permits unrestricted use, distribution, and reproduction in any medium, provided the original author and source are credited. 
Citation: Workagegn KB, Ababbo ED, Tossa BT (2013) The Effect of Dietary Inclusion of Jatropha curcas Kernel Meal on Growth Performance, Feed Utilization Efficiency and Survival Rate of Juvenile Nile tilapia. J Aquac Res Development 4: 193 doi:10.4172/2155-9546.1000193

Page 2 of 5

from Hawassa bio-diesel factory, while the basal feed ingredients such as wheat, maize, sorghum, rice, niger seed, ground nut, bone meal and soybean were purchased from local market. After collection, all the feed ingredients were dried in oven for $24 \mathrm{~h}$, at $70^{\circ} \mathrm{C}$ and mixed in different proportion as described in Table 1. After this, all the five experimental diets were divided into two parts. The first part of the five experimental diets were autoclaved at $12^{\circ} \mathrm{C} 45 \%$ moisture, 15 minutes while the rest part of the diets were not. Later, both heat treated and heat untreated diets were pelleted and then subsequently sun dried before use [17].

\section{Fish and experimental design}

Healthy juvenile Nile tilapia of mixed-sex with an average body weight of $2.36 \mathrm{~g}$ fish-1 were collected from Lake Hawassa in March 2012. The fish were allowed to acclimatize for fifteen days until the fish become more active and stopped mass mortality. During the acclimatization period, the fish were fed with locally available fish feed. Dead and weakened fish were removed daily. After acclimatization period, the experimental fish were held in $80 \mathrm{~cm} \times 30 \mathrm{~cm} \times 35 \mathrm{~cm}$ glass aquaria filled with 80 -litre tap water. The fish were fed diets containing different proportion of JCSM for 65 days. 10 fish were stocked at each glass aquarium in triplicates. Each aquarium was equipped with an air stone for continuous aeration. Faeces and uneaten feed residuals were siphoned out of the aquarium each day, while the water in each aquarium was changed every two days with $100 \%$ of water volume with fresh tap water [18]. The water quality was kept as follow; $\mathrm{pH} 7.8$, temperature $23.5^{\circ} \mathrm{C}$ and dissolved oxygen $8.5 \mathrm{mg} \mathrm{L}^{-1}$ measured using Hydrolab Model "Multi 340I/SET".

\section{Feeding regime}

The experimental fish were fed three times a day at the rate of $10 \%$ body weight as previously used by Kassaye [19]. During the experimental period, the amount of feed was adjusted once in two weeks intervals based on the body weight of the fish for the subsequent weeks. Thus, the amount of daily feed ratio (DFR) at each sampling time was calculated using the average body weight (ABW) and the total number of the fish $(\mathrm{N})$ and the feeding rate per day (FR d-1) using $\mathrm{DFR}=\mathrm{ABW} \times \mathrm{N} \times \mathrm{FR} \mathrm{d}-1$ [20]. For statistical reasons, each of the dietary group was triplicate. At the end of eight weeks, the experiment was terminated.

\section{Data collection and analysis}

During the experiment, body weight and body length of the fish were measured at two weeks intervals. Total length was expressed as the distance from the tip of the snout to the end of the caudal fin. Feeding behavior and mortality of the fish were also registered throughout the experiment.

\begin{tabular}{|l|c|c|c|c|c|}
\hline \multirow{2}{*}{ Ingredients } & \multicolumn{5}{|c|}{ Experimental diets } \\
\cline { 2 - 6 } & $\mathbf{0 \%}$ JCKM & $\mathbf{1 0 \%}$ JCKM & $\mathbf{2 0 \%}$ JCKM & $\mathbf{3 0 \%}$ JCKM & $\mathbf{4 0 \%}$ JCKM \\
\hline Wheat & 12 & 10.8 & 9.6 & 8.4 & 7.2 \\
\hline Maize & 9 & 8.1 & 7.2 & 6.3 & 5.4 \\
\hline Sorghum & 7 & 6.3 & 5.6 & 4.9 & 4.2 \\
\hline Rice & 10 & 9 & 8 & 7 & 6 \\
\hline Niger seed & 4 & 3.6 & 3.2 & 2.8 & 2.4 \\
\hline Ground nut & 7 & 6.3 & 5.6 & 4.9 & 4.2 \\
\hline Bone meal & 9 & 8.1 & 7.2 & 6.3 & 5.4 \\
\hline Soybean & 42 & 37.8 & 33.6 & 29.4 & 25.2 \\
\hline JKM & 0 & 10 & 20 & 30 & 40 \\
\hline Total & 100 & 100 & 100 & 100 & 100 \\
\hline
\end{tabular}

Table 1: Composition of experimental diets in present of Jatropha curcas Kerne Meal (JCKM).

\begin{tabular}{|c|c|c|c|c|c|}
\hline \multirow{2}{*}{$\begin{array}{l}\text { Growth } \\
\text { parameters }\end{array}$} & \multicolumn{5}{|c|}{ Experimental diets } \\
\hline & $0 \%$ JCKM & $10 \%$ JCKM & $20 \%$ JCKM & $30 \%$ JCKM & $40 \%$ JCKM \\
\hline $\begin{array}{l}\text { Initial body weight } \\
\left(\mathrm{g} \text { fish }{ }^{-1}\right)\end{array}$ & $2.3 a$ & $2.4 a$ & $2.3 a$ & $2.4 a$ & $2.4 a$ \\
\hline $\begin{array}{l}\text { Initial body length } \\
(\mathrm{cm})\end{array}$ & $5.3 a$ & $5.4 a$ & $5.3 a$ & $5.3 a$ & $5.3 a$ \\
\hline $\begin{array}{l}\text { Final body weight } \\
(\mathrm{g} \text { fish-1) }\end{array}$ & $27.5 a$ & $24.9 a$ & $18.6 b$ & $15.7 b$ & $12.3 c$ \\
\hline $\begin{array}{l}\text { Body weight gain } \\
(\mathrm{g} \mathrm{fish}-1)\end{array}$ & $25.2 a$ & $22.5 b$ & $16.3 c$ & $13.4 d$ & $9.9 e$ \\
\hline $\begin{array}{l}\text { Final body length } \\
(\mathrm{cm})\end{array}$ & $12.9 a$ & $12.0 \mathrm{ab}$ & $11.2 \mathrm{bc}$ & $10.2 \mathrm{~cd}$ & $9.3 d$ \\
\hline $\begin{array}{l}\text { Specific growth } \\
\text { rate }\left(\% \text { day }^{-1} \text { fish }^{-1}\right)\end{array}$ & $4.1 \mathrm{a}$ & $3.9 b$ & $3.5 \mathrm{c}$ & $3.2 \mathrm{~d}$ & $2.7 e$ \\
\hline $\begin{array}{l}\text { Feed conversion } \\
\text { ratio }\end{array}$ & $2.2 a$ & $2.4 a$ & $3.1 \mathrm{~b}$ & $3.9 \mathrm{c}$ & $5.9 d$ \\
\hline Feeding efficiency & $0.46 a$ & $0.42 a$ & $0.32 b$ & $0.26 c$ & $0.17 d$ \\
\hline $\begin{array}{l}\text { Fulton condition } \\
\text { factor }\end{array}$ & $1.17 a$ & $1.32 b$ & $1.16 a$ & $1.25 c$ & $1.22 \mathrm{c}$ \\
\hline Survival rate (\%) & $90 a$ & $90 a$ & $70 b$ & $40 c$ & $30 d$ \\
\hline
\end{tabular}

*Mean values in the same row having the same letters are not significantly different $(\mathrm{P}>0.05)$.

Table 2: Mean values of performance and survival rate of juvenile Nile tilapia fed different proportion of heat treated Jatropha curcas Kernel Meal (JCKM).

Based on the data collected during the experimental period, growth performance in terms of final body weight (FBW), body weight gain (BWG) and specific growth rate (SGR), and feed utilization efficiency in terms of feed conversion ratio (FCR) and feeding efficiency (FE) were evaluated. Fulton condition factor (FCF) and survival rate (SR) were also determined.

The values for these parameters were calculated using the following formula described by Ridha [2] and Hardy [21]. These are:

- BWG $\left(\mathrm{g} \mathrm{fish}^{-1}\right)=[(\mathrm{FBW}-\mathrm{IBW}) / \mathrm{IBW}]$;

- SGR $\left(\%\right.$ day $^{-1}$ fish $\left.^{-1}\right)=[(\operatorname{lnFBW}-\operatorname{lnIBW}) / \mathrm{dt}] \times 100$;

- FCR=FI (g)/BWG (g);

- $\mathrm{FE}=\mathrm{BWG}(\mathrm{g}) / \mathrm{FI}(\mathrm{g})$;

- $\mathrm{FCF}=\mathrm{BWG}(\mathrm{g}) / \mathrm{TL}(\mathrm{cm})^{3} \times 100$;

- $\mathrm{SR}=(\mathrm{NSF}-\mathrm{NDF}) / \mathrm{NSF} \times 100$;

where IBW: Initial Body Weight; dt: number of trial days; FI: Feed Intake; TL: Total Length; NSF: Number of Stocked Fish and NDF: number of dead fish

\section{Statistical analysis}

All data were subjected to a one-way analysis of variance ANOVA, and the significance of the differences between mean values were tested using turkey's multiple range test $(\mathrm{P}<0.05)$ using Minitab software, version 15.

\section{Results}

Feeding behaviour of the fish and palatability of the feed were also observed. Based on visual observation during feeding time, the fish fed control diets and $10 \%$ of heat treated JCKM had more active feeding behaviour than the fish fed the rest of the experimental diets. Moreover, palatability of all the experimental diets were not uniform in which the palatability of both the control diets and 10\% JCKM heat treated diet had relatively higher palatability than the rest of the experimental diets.

The highest growth performance (Table 2 And 3) of juvenile Nile 
Citation: Workagegn KB, Ababbo ED, Tossa BT (2013) The Effect of Dietary Inclusion of Jatropha curcas Kernel Meal on Growth Performance, Feed Utilization Efficiency and Survival Rate of Juvenile Nile tilapia. J Aquac Res Development 4: 193 doi:10.4172/2155-9546.1000193

Page 3 of 5

\begin{tabular}{|c|c|c|c|c|c|}
\hline \multirow{2}{*}{$\begin{array}{l}\text { Growth } \\
\text { parameters }\end{array}$} & \multicolumn{5}{|c|}{ Experimental diets } \\
\hline & 0\% JCKM & $10 \%$ JCKM & $20 \%$ JCKM & $30 \%$ JCKM & $40 \%$ JCKM \\
\hline $\begin{array}{l}\text { Initial body weight } \\
\left(\mathrm{g} \mathrm{fish}^{-1}\right)\end{array}$ & $2.4 a$ & $2.3 a$ & $2.3 a$ & $2.4 a$ & $2.4 a$ \\
\hline $\begin{array}{l}\text { Initial body length } \\
(\mathrm{cm})\end{array}$ & $5.3 a$ & $5.3 a$ & $5.2 a$ & $5.2 a$ & $5.2 a$ \\
\hline $\begin{array}{l}\text { Final body weight } \\
\left(\mathrm{g} \mathrm{fish}^{-1}\right)\end{array}$ & $25.3 a$ & $15.8 \mathrm{~b}$ & $13.6 \mathrm{c}$ & $11.4 \mathrm{~d}$ & $9.2 d$ \\
\hline $\begin{array}{l}\text { Body weight gain } \\
\left(\mathrm{g} \mathrm{fish}^{-1}\right)\end{array}$ & $22.9 a$ & $13.4 \mathrm{~b}$ & $11.3 \mathrm{c}$ & $9.0 d$ & $6.8 \mathrm{e}$ \\
\hline $\begin{array}{l}\text { Final body length } \\
(\mathrm{cm})\end{array}$ & $12.1 \mathrm{a}$ & $10.1 \mathrm{~b}$ & $9.4 \mathrm{c}$ & $8.8 d$ & $8.5 d$ \\
\hline $\begin{array}{l}\text { Specific growth } \\
\text { rate }\left(\% \text { day }^{-1}\right. \\
\left.\text { fish }^{-1}\right)\end{array}$ & $3.9 a$ & $3.2 \mathrm{~b}$ & $3.0 \mathrm{~b}$ & $2.6 \mathrm{c}$ & $2.2 \mathrm{c}$ \\
\hline $\begin{array}{l}\text { Feed conversion } \\
\text { ratio }\end{array}$ & $2.5 a$ & $3.3 b$ & $4.1 \mathrm{c}$ & $7.6 d$ & $8.8 \mathrm{e}$ \\
\hline Feeding efficiency & $0.40 \mathrm{a}$ & $0.31 \mathrm{~b}$ & $0.25 \mathrm{c}$ & $0.13 d$ & $0.11 d$ \\
\hline $\begin{array}{l}\text { Fulton condition } \\
\text { factor }\end{array}$ & $1.31 a$ & $1.31 a$ & $1.37 \mathrm{~b}$ & $1.32 \mathrm{a}$ & $1.10 \mathrm{c}$ \\
\hline Survival rate (\%) & $90 a$ & $70 \mathrm{~b}$ & $50 \mathrm{~b}$ & $30 d$ & $30 d$ \\
\hline
\end{tabular}

*Mean values in the same row having the same letters are not significantly different $(\mathrm{P}>0.05)$.

Table 3: Mean values of performance and survival rate of juvenile Nile tilapia fed different proportion of heat untreated Jatropha curcas Kernel Meal (JCKM).

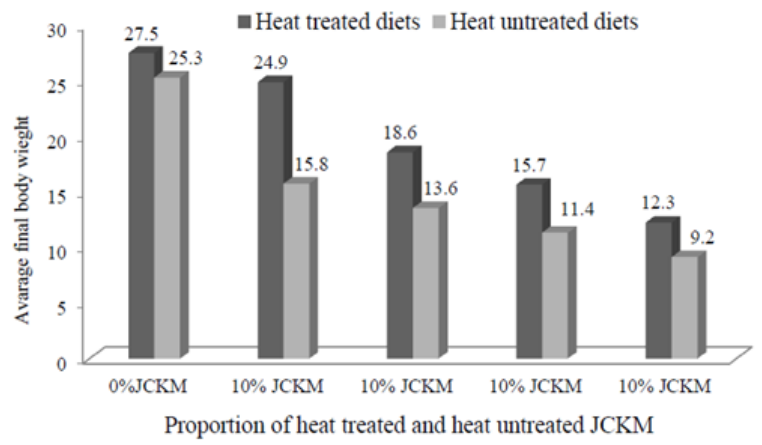

Figure 1: Final body weight of fish fed different proportion of Jatropha curcas Kernel Meal (JCKM) before and after heat treatment.

tilapia in terms of FBW, BWG and SGR, and survival rate were observed on the fish fed heat treated control diet followed by heat untreated control diet and 10\% heat treated JCKM (Figure 1). Similarly, the best feed utilization efficiency of juvenile Nile tilapia in terms of FCR and FE was observed on the fish fed control diets and 10\% heat treated JCKM. Fish fed the rest of the experimental diets had significantly $(\mathrm{P}<0.05)$ lower growth performance, survival rate, and feed utilization efficiency (Table 2 and 3). The Fulton's condition factors of the fish fed with all the experimental diets were also significantly different $(\mathrm{P}<0.05)$ among the fish fed different experimental diets.

Similarly, the weekly growth trend of fish for all experimental groups is demonstrated by Figures 2 and 3. The mean values of weekly base body weight indicate that second week onward there was differential growth trends among the fish fed control and test diets. Variation on growth trend was increased towards the end of the experiment.

\section{Discussion}

The average values of all the recorded water quality parameters were not significantly different $(\mathrm{P}>0.05)$, and were within a suitable range for the normal growth of Nile tilapia as mentioned by Azzaza et al. and Xu

et al. [22,23]. Similarly, the initial body weight and body length of the fish recorded at the beginning of the experiment were not significantly different $(\mathrm{P}>0.05)$. Therefore, the performance variation of the fish among treatments was due to the effect of dietary inclusion of JCKM.

The present study confirmed that dietary inclusion of JCKM at different proportion to the diet of Nile tilapia showed remarkable variation on palatability of the diets, and feeding behaviour, growth performance, feed utilization efficiency and survival rate of fish (Tables 2 and 3). Fish fed with control diets and $10 \%$ of heat treated JCKM had significantly $(\mathrm{P}<0.05)$ higher growth performance and survival rate with better feed utilization efficiency and had more active feeding behaviour than the fish fed the rest of the diets. These diets also had better palatability than the rest of the experimental diets. The reason might be due to low amount of anti-nutritional factors that affects the taste of the diets and also limits the availability of nutrients in those diets [5].

The highest growth performance in terms of FBW $\left(27.5 \mathrm{~g} \mathrm{fish}^{-1}\right)$, BWG (24.9 $\left.\mathrm{g} \mathrm{fish}^{-1}\right)$ and SGR (4.1\% day ${ }^{-1}$ fish $\left.^{-1}\right)$ was observed on the fish fed heat treated control diet followed by the fish fed heat untreated control diet (25.3 $\mathrm{g} \mathrm{fish}^{-1}$ for FBW, $22.9 \mathrm{~g} \mathrm{fish}^{-1}$ for BWG and 3.9\% day ${ }^{-1}$ fish $^{-1}$ for SGR), and 10\% heat treated JCKM (24.9 $\mathrm{g} \mathrm{fish}^{-1}$ for FBW, 22.5 $\mathrm{g} \mathrm{fish}^{-1}$ for BWG and $3.9 \%$ day $^{-1}$ fish $^{-1}$ for SGR) and were significantly $(\mathrm{P}<0.05)$ higher than the fish fed the rest of the diets. The present results confirmed the earlier work of Azzaza et al. Reddy and Pierson, Hajos et al. and Aderibigbe et al. [7,14-16] who reported that feed with higher concentration of anti-national factors reduces the availability

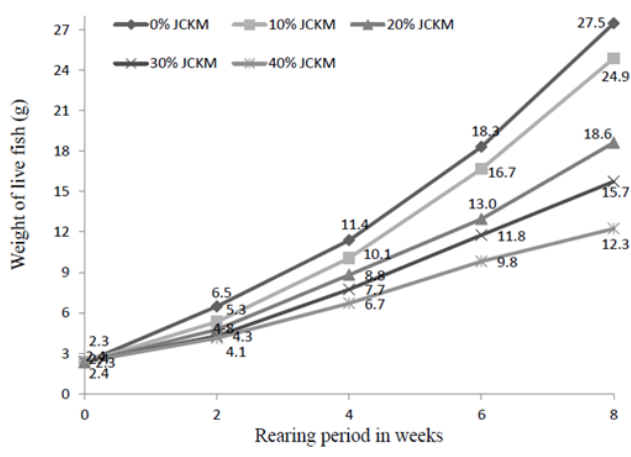

Figure 2: Growth performance of juvenile Nile tilapia fed different proportion of heat treated Jatropha curcas Kernel Meal (JCKM).

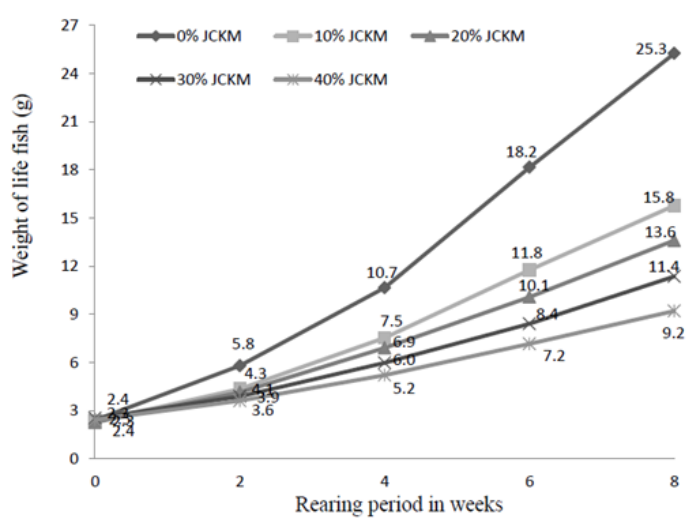

Figure 3: Growth performance of juvenile Nile tilapia fed different proportion of heat untreated Jatropha curcas Kernel Meal (JCKM). 
Citation: Workagegn KB, Ababbo ED, Tossa BT (2013) The Effect of Dietary Inclusion of Jatropha curcas Kernel Meal on Growth Performance, Feed Utilization Efficiency and Survival Rate of Juvenile Nile tilapia. J Aquac Res Development 4: 193 doi:10.4172/2155-9546.1000193

Page 4 of 5

of nutrients which intern reduces the growth performance of the fish. Similarly, the highest survival rate was achieved on the fish fed with control diets and $10 \%$ heat treated JCKM (90\%), and had significantly $(\mathrm{P}<0.05)$ higher as compared to the survival rate of fish that fed rest of the experimental diets.

Lower growth performance and survival rate of fish fed higher proportion of JCKM might be due to higher level of anti-nutritional factors such as phytic acid and saponins. Since these substances are relactant to reduce with simple heat treatment, they can be found in higher concentration in the diets with higher proportion of dietary JCKM $[16,24]$. As reported by Azzaza et al. and Reddy and Pierson $[7,14]$, higher proportion of phytic acid in fish diets reduces the digestibility of protein and the bioavailability of minerals (especially $\mathrm{Ca}^{2+}$ and $\mathrm{Fe}^{2+}$ ) and thus, depresses the growth performance of fish that fed higher proportion of dietary JCKM, especially for heat untreated diets. Similarly, the best feed utilization efficiency in terms of FCR (2.2) and FE (0.46) was observed on fish fed heat treated control diet followed by the fish fed heat untreated control diet ( 2.4 for FCR, and 0.42 for FE), and $10 \%$ heat treated JCKM ( 2.5 for FCR, and 0.40 for FE), and were not significantly different among the fish reared in the three treatment groups. The similarity of these results suggests that digestibility and absorption of nutrients from those diets were similar and lead to have similar growth performance. This implies nutrient utilization values found in this study for those diets signify very good utilization of the diets. However, feed utilization efficiency of the fish fed the rest of the experimental diets had significantly low. These results are in line with the work of Azzaza et al. Kumar et al. and Reddy and Pierson [7,11,14] who reported that the level of incorporation of JCKM had an effect on digestibility and absorption of nutrients which intern increase wastage of nutrients via faeces. The Fulton's condition factors of the fish fed all the experimental diets were also significantly different $(\mathrm{P}<0.05)$ among the fish fed different experimental diets. This implies that the level of JCKM in the fish diet could affect the condition factor of the fish.

Although the growth performance and feed utilization efficiency of the fish fed the above three diets were not significantly vary, substantially higher growth performance with better feed utilization efficiency were observed on the fish fed heat treated control diet compared to heat untreated control diet and 10\% heat treated JCKM (Figure 1). This implies that heat treatment can increase the palatability of feed and availability of nutrients and thus, increase the growth performance of the fish fed those diets. Similar observation was reported earlier in Nile tilapia [24], in common carp [11,25] in pig [17]. The present results also confirmed the earlier work of Azzaza et al. [7] who reported that moist heat treatment can reduce the percentage of some heat liable anti-nutritional factors such as trypsin inhibitors and total phenols. The authors also stated that the level of these substances can be further reduced when the diet is treated by both $4 \% \mathrm{NaOH}$ plus moist heat treatment. Goel et al. [26] also stated that the level of phorbol-ester, the only toxic substance in JCKM, can reduce by simple heat treatment followed by chemical treatments [26].

In general, the present results revealed that the lowest feed utilization efficiency of fish fed higher proportion of dietary JCKM leads to decrease the growth performance. The reason might be due to higher level of anti-nutrimental factors that could reduce nitrogen and lipid content through faeces [15]. The authors also stated that higher antinutritional factors and toxic substances reduce the metabolic activities of the fish which in turn reduce the growth performance. Moreover, higher concentration of the anti-nutritional factors reduces the digestibility of protein in the diets $[11,27]$. In addition, dietary JCKM at higher proportion (above 10\% JCKM) with simple heat treatment reduces the availability of dietary protein of the feed and consequently reduces the performance of Nile tilapia. However, inclusion of dietary JCKM up to $10 \%$ JCKM increases the performance and survival rate of the fish.

\section{Conclusion}

The overall growth performance, feed utilization efficiency and survival rate of fish fed with dietary inclusion up to $10 \%$ of heat treated JCKM and the control diets were similar. Thus, inclusion of dietary JCKM at lower level (up to 10\% JCKM) with simple heat treatment can be a good dietary protein source for juvenile Nile tilapia. Therefore, JCKM is one of a promising feed ingredient in the future to replace the most important and limited protein sources such as fish meal, fish oil and soybean meal with simple detoxification methods. The percentage of dietary inclusion of JCKM can increase by applying different detoxification methods such as chemical treatment and biological treatments or combination of them.

\section{Acknowledgment}

The research was financially supported by NORAD project, Hawassa University. The authors would like to thank to Dr. Andargachew Gedebo for his contribution towards facilitating of the financial aspect. The authors also acknowledge to Engineer Eshetu Desalegn for his willingness to provide the JCKM from his bio-diesel factory.

\section{References}

1. Fapohunda OO, Fagbenro OA (2006) Biotechnical factors affecting tilapia culture systems in the savanna region of Nigeria. Proceedings of the south international symposium on Tilapia in aquaculture, Veracruz, Mexico.

2. Ridha MT (2006) Comparative study of growth performance of three strains of Nile tilapia, Oreochromis niloticus, L. at two stocking densities. Aquac Res 37 172-179.

3. FAO (2012) The State of World Fisheries and Aquaculture Part I: World Review of Fisheries and Aquaculture, Rome, Italy.

4. FAO (2010) The State of World Fisheries and Aquaculture Part 1: World Review of Fisheries and Aquaculture, Rome, Italy.

5. Makkar HPS, Becker K, Sporer F, Wink M (1997) Studies on Nutritive Potentia and Toxic Constituents of Different Provenances of Jatropha curcas. J Agric Food Chem 45: 3152-3157.

6. Becker K, Makkar HPS (2008) Jatropha curcas: A potential source for tomorrow's oil and biodiesel. Lipid Tech 20: 104-107.

7. Azzaza NAE, El-Nisr NA, Elsharkawy EE, Elmotleb EA (2011) Chemical and Pathological Evaluation of Jatropha curcas Seed Meal Toxicity With or Without Heat and Chemical Treatment. Aus J Basic and Applied Sci 5: 49-59.

8. Kumar V, Khalil WK, Weiler U, Becker K (2013) Influences of incorporating detoxified Jatropha curcas kernel meal in common carp (Cyprinus carpio L.) diet on the expression of growth hormone- and insulin-like growth factor-1encoding genes. J.Anim Physiol Anim Nutr 97: 97-108.

9. Madalla N (2008) Novel Feed Ingredients for Nile Tilapia (Oreochromis niloticus L.). PhD, Dissertation, Stirling University, Scotland, UK.

10. Tacon AGJ, Foster IP (2000) Global trends and challenges to aquaculture and aqua-feed development in the new millennium. International Aqua-feed Directory and buyers Guide 2001, Trust RAL, Uxbridge, Middlesex, UK.

11. Kumar V, Makkar HPS, Becker K (2008) Detoxification of Jatropha curcas seed meal and its utilization as a protein source in fish diet. Comp Biochem Phys A 151: 13-19.

12. Makkar HPS, Francis G, Becker K (2008) Protein concentration from Jatropha curcas screw-pressed seed cake and toxic and antinutrimental factors in protein concentrate. J Sci Food Agr 88: 1542-1548.

13. Parawira W (2010) Biodiesel production from Jatropha curcas: A Review. Science Research and Essays 5: 1796-1808. 
Citation: Workagegn KB, Ababbo ED, Tossa BT (2013) The Effect of Dietary Inclusion of Jatropha curcas Kernel Meal on Growth Performance, Feed Utilization Efficiency and Survival Rate of Juvenile Nile tilapia. J Aquac Res Development 4: 193 doi:10.4172/2155-9546.1000193

Page 5 of 5

14. Reddy NR, Pierson MD (1994) Reduction in antinutritional and toxic components in plant foods by fermentation. Food Res Int 27: 281-290.

15. Hajos G, Gelenser E, Pusztai A, Grant G, Sakhri M, et al. (1995) Biological Effects and Survival of Trypsin Inhibitors and Agglutinin from Soybean in Small Intestine of the Rat. J Agric Food Chem 43: 165-170.

16. Aderibigbe AO, Jonson CO, Makkar HPS, Becker K, Foidl N (1997) Chemical composition and effects of heat on organic matter- and nitrogen-degradability and some antinutritional components of Jatropha meal. Anim Feed Sci Tech 65: 223-243.

17. Wang H, Yi C, Zhao Y, Liu H, Liu J, et al. (2011) Effect of replacing soybean meal by detoxified Jatropha curcas kernel meal in the diet of growing pigs on their growth, serum biochemical parameters and visceral organs. Anim Feed Sci Tech 170: 141-146.

18. El-Sherif MS, El-Feky AMI (2009) Performance of Nile Tilapia, (Oreochromis niloticus) Fingerlings: I. Effect of pH. Int Agri Biol 11: 297-300.

19. Kassaye BW (2012) Evaluation of Growth Performance, Feed Utilization Efficiency and Survival Rate of Juvenile Nile tilapia, Oreochromis niloticus (Linnaeus, 1758) Reared at Different Water Temperature. Int J Aquaculture 2: 59-64.

20. Nandlal S, Pickering T (2004) Tilapia fish farming in Pacific Island countries:
Tilapia Hatchery Operation. Noumea, New Caledonia: Secretariat of the Pacific Community.

21. Hardy RW (2003) Diet Formulation and Manufacture. In: Fish Nutrition (3rd Edition), London, Academic Press.

22. Azzaza MS, Dhrajef MN, Krajem MM (2008) Effects of water temperature on growth and sex ratio of juvenile Nile tilapia Oreochromis niloticus (Linnaeus) reared in geothermal water in southern Tunisia. J Therm Biol 33: 98-105.

23. Xu JY, Miao XW, Liu Y, Cui SR (2005) Behavioral response of tilapia (Oreochromis niloticus) to acute ammonia stress monitored by computer vision. J Zhejiang Univ Sci B 6: 812-816.

24. Abo-state HA, Tahoun AM, Hammouda YA (2009) Effect of Replacement of Soybean meal by DDGS Combined with Commercial Phytase on Nile Tilapia. (Oreochromis niloticus) Fingerlings Growth Performance and Feed Utilization. Am Eur J Agric Environ Sci 5: 437-479.

25. Mazurkiewicz J (2009) Utilization of domestic plant components in diets for common carp Cyprinus carpio L. Arch Pol Fish 17: 5-39.

26. Goel G, Makkar HP, Francis G, Becker K (2007) Phorbol esters: structure, biological activity, and toxicity in animals. Int J Toxicol 26: 279-288.

27. Becker K, Makkar HP (1998) Effects of phorbol esters in carp (Cyprinus carpio L). Vet Hum Toxicol 40: 82-86. 